\title{
Nutritional status changes in children with malignant solid tumor before and after chemotherapy
}

\author{
Boris Januar, MD; Sri S Nasar, MD; Rulina Suradi, MD; Maria Abdulsalam, MD
}

\begin{abstract}
Background Although aggressive multimodal treatment programs in childhood cancer have significantly increased survival rates, the morbidity caused by protein energy malnutrition related to therapy is still high.

Objective To describe nutritional status changes in children with malignant solid tumors after 21 days of chemotherapy.

Methods A descriptive prospective study with pre- and post-test design in children with malignant solid tumors was conducted in the Department of Child Health, Medical School University of Indonesia/Cipto Mangunkusumo Hospital, Jakarta between January and July 2004. Anthropometrics (body weight, BW and midupper-arm circumference, MUAC) and serum albumin measurements were performed before and after 21 days of chemotherapy. Results Twenty-two children were enrolled in this study. After 21 days of chemotherapy, 8 children had decreased BW and 6 children had decreased MUAC, but 3 children gained weight and had increased MUAC. Based on MUAC-for-age, 7 children had decreased nutritional status. Fifteen children had reduced serum albumin levels based on a $10 \%$ cut-off point. The number of children who had reduced serum albumin was larger than those who had reduced $\mathrm{BW}$ and MUAC. In the evaluation of average oral food consumption during 21 days, 7 out of 16 children could accept more than $2 / 3$ portion of served food. All of the children who received enteral feeding could accept more than $2 / 3$ portion of served food.

Conclusion There was a decrease of nutritional status, BW, MUAC, and serum albumin in most of the subjects after chemotherapy. Serum albumin level measurement was the more sensitive parameter in determining nutritional status changes. Enteral feeding seems more appropriate to fulfill nutritional needs than oral feeding [Paediatr Indones 2005;45:166-170].
\end{abstract}

Keywords: nutritional status, anthropometrics, serum albumin, enteral feeding, malignant solid tumor, chemotherapy
$\mathrm{P}$ oor nutritional status is frequently observed in children with cancer. It can be caused by the cancer itself, the treatment administered, or both. ${ }^{1-5}$ In the past 20 years, significant advances have been made in childhood cancer treatment. Although aggressive multimodal treatment programs have significantly increased survival, the morbidity caused by protein energy malnutrition related to therapy still increases. ${ }^{3}$ Poor nutritional status has a significant negative impact on the ability to tolerate treatment as well as on the quality and duration of life. Twenty percent of deaths from malignancies are due to malnutrition and tissue wasting. ${ }^{6}$

The aim of this study is to describe nutritional status changes in children with malignant solid tumors after chemotherapy.

\section{Methods}

A descriptive prospective study with pre- and post-test design in children with malignant solid tumor was

From the Department of Child Health, Medical School, University of Indoneisa, Jakarta, Indonesia.

Reprint requests to: Boris Januar, MD, Nutrition and Metabolic Division, Department of Child Health, Medical School, University of Indonesia, Cipto Mangunkusumo Hospital, Jakarta, Indonesia. Tel. 62-21-3907742; Fax. 62-21-3907743. 
Boris Januar et al: Nutritional status in children with malignant solid tumor before and after chemotherapy

Table 1. Nutritional status (MUAC-for-age) before and after 21 days of CHEMOTHERAPY

\begin{tabular}{lcccc}
\hline MUAC-for-age & & \multicolumn{3}{c}{ After } \\
\cline { 3 - 5 } & Before & Well-nourished & Undernourished & Malnourished \\
\hline Well-nourished & 11 & 6 & 5 & - \\
Undernourished & 9 & - & 7 & 2 \\
Malnourished & 2 & - & - & 2 \\
\hline Total & 22 & 6 & 12 & 4
\end{tabular}

Table 2. Serum albumin before and after 21 days of CHEMOTHERAPY

\begin{tabular}{lccc}
\hline \multirow{2}{*}{ Serum albumin } & \multicolumn{2}{c}{ After } \\
\cline { 3 - 4 } & Before & Normal & Hypoalbuminemia \\
\hline Normal & 14 & 5 & 9 \\
Hypoalbuminemia & 8 & 2 & 6 \\
\hline Total & $\mathbf{2 2}$ & $\mathbf{7}$ & $\mathbf{1 5}$ \\
\hline
\end{tabular}

conducted in the Department of Child Health, University of Indonesia/Cipto Mangunkusumo Hospital between January and July 2004. Subjects were recruited by consecutive sampling. Children were included if they were between 1-18 years of age, hospitalized for chemotherapy in the Pediatric Oncology Ward, Cipto Mangunkusumo Hospital, and had informed consent from their parents. We excluded children who had congenital anomalies, chronic diarrhea, or malabsorbtion at the time chemotherapy was started. Non-cooperative children and children who underwent surgery or radiotherapy were also excluded.

Anthropometrics and serum albumin level measurements were performed before and after 21 days of chemotherapy. Twenty-one days was used as the interval between the first and second measurements, since the half life of albumin in blood is about 14-20 days. $2,7,8$ In patients with dehydration, all examinations were performed after the subjects were rehydrated. The anthropometrics measurements performed were mid-upper-arm circumference (MUAC) and body weight (BW). Serum albumin concentrations were examined according to the Brom Crisol Green method.

The anthropometrics standard used for interpretation in this study was the $1983 \mathrm{NCHS}$ standard. Normal serum albumin level was defined as $33.5 \mathrm{~g} / \mathrm{dl}$ and values less than $3.5 \mathrm{~g} / \mathrm{dl}$ were considered as hypoalbuminemia. ${ }^{9,10}$ Body weight and MUAC changes of more than $5 \%$ were considered clinically important. ${ }^{7,11}$ Changes in serum albumin level were considered clinically important if the difference was more than $10 \% .^{12}$

Food consumption was defined as an evaluation of feeding or dietary response, i.e., the average amount of the served food during 21 days which is consumed by the patient. Food consumption of more than $2 / 3$ of the served food was considered as sufficient and comsumption of less than $2 / 3$ as insufficient. ${ }^{9}$ Enteral nutrition was given via nasogastric tube.

The study protocol was approved by the Medical Research Ethics Commiittee of the Medical School, University of Indonesia.

\section{Results}

Out of 26 patients ( 15 boys and 11 girls) who fulfilled the inclusion criteria, only 22 children could be observed for 21 days. Two children died before the end of the study period and 2 did not come for followup after 21 days. The subjects' age ranged between 1 to 11 years and most subjects $(19 / 22)$ were less than five years old.

The types of cancers in our subjects were retinoblastoma (10 subjects), rhabdomyosarcoma (7 subjects), neuroblastoma (5 subjects), Wilms' tumor (2 subjects), Ewing's sarcoma (1 subject), and ovarian teratoma (1 subject). 
After 21 days of chemotherapy there were 7 children with decreased MUAC-for-age. No subject had increased nutritional status based on MUAC-for-age (Table 1). Before the initiation of chemotherapy, there were 8 children with hypoalbuminemia. After 21 days of chemotherapy there were 15 children with hypoalbuminemia, and 2 previously hypoalbuminemic children regained normal albumin levels (Table 2).

There were 15 children with decreased albumin levels but only 5 children with decreased body weight and 6 children with decreased MUAC (Table 3).

Table 4 shows the average food consumption at 21 days of chemotherapy. In the first week of chemotherapy, 18 patients received oral feeding and 4 received enteral nutrition. In the second and third week, 16 children received oral feeding and 6 received enteral nutrition. Two of the children who received oral feeding in the first week had to be reassigned to enteral nutrition due to severe stomatitis. Most of the children could only consume less than $2 / 3$ portion of their meals in the first week of chemotherapy. In the second and third week, more than half of the children could accept more than $2 / 3$ portion. All children with enteral nutrition could tolerate more than $2 / 3$ portion in the second and third week.

\section{Discussion}

The ratio of boys and girls with malignant solid tumor in this study was $1.4: 1$, similar to that in a study by Fernbach and Vietti. ${ }^{13}$ Most of our patients were between 1 to 5 years old (19/22 children). This was in accordance with data obtained by Stiller and Draper in Great Britain. ${ }^{14}$ In our study, the types of cancers in order of decreasing frequency were retinoblastoma, rhabdomyosarcoma, neuroblastoma, Wilms' tumor, Ewing's sarcoma, and ovarian teratoma. These findings differ from Kupfer's, ${ }^{15}$ in whose study this order was neuroblastoma, Wilms' tumor, retinoblastoma, and Ewing's sarcoma. The small sample size in our study may have caused this difference.

MUAC gives information about the condition of muscular tissue and subcutaneous fat. Nowadays, MUAC-for-age is a nutritional status indicator of choice. ${ }^{9}$ MUAC shows that inadequate calorie intake will cause mobilization of body reserves. ${ }^{7,9}$ In our study, after 21 days of chemotherapy 7 children had decreased MUAC-for-age and none had increased MUAC-for-age. These findings may reflect the severity of the disease, increased nutritional needs due to the disease, and chemotherapy side effects if not sup-

Table 3. Nutritional characteristics of study subjects after 21 days OF CHEMOTHERAPY

\begin{tabular}{|c|c|c|c|c|}
\hline \multirow[t]{2}{*}{ Characteristics } & \multirow[t]{2}{*}{$\mathbf{n}$} & \multicolumn{3}{|c|}{ Albumin level changes } \\
\hline & & $\begin{array}{c}\text { Increased }>10 \% \\
(n=2)\end{array}$ & $\begin{array}{c}\text { Constant } \\
(n=5)\end{array}$ & $\begin{array}{c}\text { Decreased }>10 \% \\
(n=15)\end{array}$ \\
\hline \multicolumn{5}{|l|}{ BW changes } \\
\hline - Increased $\geq 5 \%$ & 3 & 2 & - & 1 \\
\hline - Stable & 11 & - & 2 & 9 \\
\hline $\begin{array}{l}\text { - Decreased } \geq 5 \% \\
\text { MUAC changes }\end{array}$ & 8 & - & 3 & 5 \\
\hline - Increased $\geq 5 \%$ & 3 & 1 & 1 & 1 \\
\hline - Stable & 13 & 1 & 4 & 8 \\
\hline - Decreased $\geq 5 \%$ & 6 & - & - & 6 \\
\hline
\end{tabular}

TABle 4. WEEKLY FOOd CONSUMPTION DURING CHEMOTHERAPY BASED ON AVERAGE MEAL PORTION AND MODE OF NUTRITION

\begin{tabular}{|c|c|c|c|c|c|c|c|c|c|}
\hline \multirow[t]{3}{*}{ Mode of nutrition } & \multirow{3}{*}{$\mathbf{n}$} & \multicolumn{8}{|c|}{ Food consumption } \\
\hline & & \multicolumn{2}{|c|}{ Week 1} & \multirow[b]{2}{*}{$\mathbf{n}$} & \multicolumn{2}{|c|}{ Week 2} & \multirow[b]{2}{*}{$\mathbf{n}$} & \multicolumn{2}{|c|}{ Week 3} \\
\hline & & $\begin{array}{c}2 / 3 \\
\text { portion }\end{array}$ & $\begin{array}{c}<2 / 3 \\
\text { portion }\end{array}$ & & $\begin{array}{c}2 / 3 \\
\text { portion }\end{array}$ & $\begin{array}{c}<2 / 3 \\
\text { portion }\end{array}$ & & $\begin{array}{c}2 / 3 \\
\text { portion }\end{array}$ & $\begin{array}{l}<2 / 3 \\
\text { portion }\end{array}$ \\
\hline Oral & 18 & 3 & 15 & 16 & 7 & 9 & 16 & 8 & 8 \\
\hline Enteral & 4 & 2 & 2 & 6 & 6 & - & 6 & 6 & - \\
\hline Total & 22 & 5 & 17 & 22 & 13 & 9 & 22 & 14 & 8 \\
\hline
\end{tabular}


Boris Januar et al: Nutritional status in children with malignant solid tumor before and after chemotherapy

ported with adequate nutritional management. Accordingly,

Rickard et $\mathrm{al}^{4}$ stated that malnutrition is most commonly found at the time of diagnosis and worsens during chemotherapy.

Albumin is a protein with a half-life of 14-20 days in normal conditions. ${ }^{16}$ Rickard et al found that a decrease in albumin level of more than $10 \%$ showed subclinical protein energy malnutrition. ${ }^{12}$ Before chemotherapy, we found 14 children with normal albumin levels and 8 children with hypoalbuminemia (Table 2). After 21 days of chemotherapy there were more children with hypoalbuminemia (15/22 children), but there were also 2 children with previous hypoalbuminemia who regained normal albumin levels. This may be caused by adequate food consumption as an advantage of the enteral mode of delivery. The decrease in albumin level was more pronounced than that in body weight and MUAC. This condition reflects the previously mentioned subclinical protein energy malnutrition due to inadequate intake. ${ }^{12}$ In one child, body weight and MUAC increased by $35 \%$, but albumin level decreased $>10 \%$ (Table 3). Further investigation of this patient revealed increased liver transaminases to more than 5 times the normal value, which led us to assume that the decreased albumin level was due to impaired liver synthesis function. ${ }^{16}$

In the first week most of the children could only consume less than $2 / 3$ portion of the served food. This might be due to side effects of chemotherapy, which usually occur in the first week and impair dietary intake. In the second and third weeks these side effects had subsided, so that more than half of the patients could tolerate more than $2 / 3$ portion of the served food. All children who were given enteral nutrition via nasogastric tube could tolerate more than $2 / 3$ portion of served food in the second and third weeks.

In conclusion, nutritional status based on BW, MUAC, and serum albumin deteriorated in most patients with malignant solid tumor following chemotherapy. In this study, serum albumin was the more sensitive parameter in determining nutritional status changes. Enteral feeding seems to be a more appropriate method to fulfill nutritional needs than oral feeding. Further evaluation of chemotherapy-related nutritional changes in patients with malignant solid tumor is needed, preferably with larger sample size and longer duration of observation.

\section{References}

1. Donaldson SS. Effects of therapy on nutritional status of pediatric cancer patient. Cancer Res 1982;42 Suppl:729-36.

2. van Eys J. Malnutrition in children with cancer: Incidence and consequence. Cancer 1979;43:2030-5.

3. Coates TD, Rickard KA, Grosfeld JL, Weetman RM. Nutritional support of children with neoplastic diseases. Surg Clin North Am 1986;66:1197-212.

4. Rickard KA, Baehner RL, Coates TD, Weetman RM, Provisor AJ, Grosfeld JL. Supportive nutritional intervention in pediatric cancer. Cancer Res 1982;42 Suppl:766-73.

5. Rickard KA, Detamore CM, Coates TD, Grosfeld JL, Weetman RM, White NM, et al. Effect of nutrition staging on treatment delays and outcome in stage IV neuroblastoma. Cancer 1983;52:587-98.

6. Meguid MM, Laviano A. Weight loss and cachexia. In: Abeloff MD, Armitage JO, Lichter AS, Niederhuber JE, editors. Clinical Oncology. $2^{\text {nd }}$ ed. New York: Churchill Livingstone; 2000. p. 579-96.

7. Allan WW, Hendricks KM. Manual of pediatric nutrition. Philadelphia: WB Saunders; 1985. p. 1-51.

8. Mechanick JI, Brett EM. Nutrition support of the chronically critically ill patient. Crit Care Clin 2002;18:597-618.

9. Gibson RS. Nutritional assessment, a laboratory manual. New York: Oxford University Press; 1993. p. $127-42$.

10. van Eys J. Effect of nutritional status on response to therapy. Cancer Res 1982;42 Suppl:747-53.

11. Weinsier RL, Hunker HM, Krumdieck CL, Butterworth CE. Hospital malnutrition: a prospective evaluation of general medical patients during the course of hospitalization. Am J Clin Nutr 1979;32:418-26.

12. Rickard KA, Coates TD, Grosfeld JL, Weetman RM, Baehner RL. The value of nutrition support in children with cancer. Cancer 1986;58:1904-10.

13. Fernbach DJ, Vietti TJ. General aspects of childhood cancer. In: Fernbach DJ, Vietti TJ, editors. Clinical pediatric oncology. $4^{\text {th }}$ ed. St Louis: Mosby; 1991. p. 1-9.

14. Stiller CA, Draper GJ. The epidemiology of cancer in children. In: Voute PA, Kalifa C, Barrett A, editors. Cancer in children clinical management. $4^{\text {th }}$ ed. New York: Oxford University Press; 1998. p. 1-19.

15. Kupfer GM. Childhood cancer, epidemiology. [cited 2001 October $3^{\text {rd }}$ ] Available from: URL: http// 


\section{Paediatrica Indonesiana}

www.emedicine.com/ped/topic.

16. Buzby GP, Mullen JL. Nutritional assessment. In: Rombeau JL, Caldwell MD, editors. Enteral and tube feeding. Philadelphia: WB Saunders; 1984. p. 127-44.
17. Rickard KA, Grosfeld JL, Kirksey A, Ballantine TV, Baehner RL. Reversal of protein-energy malnutrition in children during treatment of advanced neoplastic disease. Ann Surg 1979;190:771-81. 